\title{
Prevalence of Tumours and Antibodies against Leukosis and Sarcoma Viruses from Subgroups A and B in Layers
}

\author{
O. TOMÁS̆EK ${ }^{1}$, P. KVAPIL ${ }^{1}$, R. HALOUZKA², L. KULÍKOVÁ ${ }^{1}$ \\ ${ }^{1}$ Avian and Exotic Animal Clinic, Faculty of Veterinary Medicine, University of Veterinary \\ and Pharmaceutical Sciences Brno, Czech Republic \\ ${ }^{2}$ Department of Patological Morphology, Faculty of Veterinary Medicine, University of Veterinary \\ and Pharmaceutical Sciences Brno, Czech Republic
}

Received February 4, 2005

Accepted November 10, 2005

\begin{abstract}
Tomášek O., P. Kvapil, R. Halouzka, L. Kulíková: Prevalence of Tumours and Antibodies against Leukosis and Sarcoma Viruses of Subgroups A and B in Layers. Acta Vet. Brno 2005, 74: 575-579.

Viruses belonging to the leukosis/sarcoma group represent a frequent cause of neoplasm in poultry. The aim of this study was to assess the frequency of tumours and the prevalence of antibodies against leukosis/sarcoma viruses from subgroups A and B in laying hens of domestic fowl (Gallus gallus $f$. domestica), both in parents and production flocks from the Czech Republic. A total of 91 flocks of laying hens from three different slaughterhouses were examined for the presence of tumours. The occurrence of neoplastic lesions was found to be low. Although tumours occurred in 82 flocks $(90.1 \%)$, their incidence in $62(68.1 \%)$ flocks was below $0.5 \%$, and it only exceeded one percent in 3 flocks (3.3\%). 9 flocks $(9.9 \%)$ had no tumours. In order to determine the spectrum of the tumours, 14 randomly collected samples were histologically examined. The tumours found in hens at the end of the laying period showed varied histogenesis (five cases of pancreatic adenocarcinoma, three cases of adenocarcinoma of the oviduct, two cases of leiomyoma of the mesosalpinx, one case of ovarian adenocarcinoma, and one case of intestinal lymphoma). Two pseudotumours, probably encapsulated egg yolks, were also found. Serologic examinations of hen blood samples from both the production and breeding flocks were made using ELISA tests. No antibodies against leukosis/sarcoma viruses from subgroups A and B were detected in this study.
\end{abstract}

Avian leukosis, enzyme-linked immunosorbent assay, poultry, histology

A leukosis/sarcoma (LS) complex is a name given to group of tumours occurring in various tissues and is caused by viruses from the genus Alpharetrovirus, family Retroviridae. The complex includes avian leukoses, tumours of endothelial, epithelial, and connective tissues, and osteopetrosis. Although the causative agent of the disease is ubiquitous on poultry farms, evident clinical manifestations of the disease are rare (Fadly and Payne 2003). The last study of the avian leukosis virus prevalence in the former Czechoslovakia was made in 1982. It assessed the virus occurrence in Leghorn Brown flocks from Slovakia and concluded that $24 \%$ of the serologically tested samples had been positive for the viral infection (Frano et al. 1982). Since there is an obvious lack of recent data on tumour prevalence in flocks of laying hens of domestic fowl in the Czech Republic, we decided to conduct tumour screening tests in poultry slaughterhouses and to closely diagnose the tumour types.

The aim of the study was to assess the tumour incidence and to identify tumour types in laying hens in both the breeding and production flocks. ELISA method was used in one breeding flock and one production flock to test the hens for the presence of antibodies against the avian leukosis of subtypes A and B.

Address for correspondence:

MVDr. Oldřich Tomášek

Klinika chorob ptáků, plazů a drobných savců

VFU Brno, Palackého 1-3, 61200 Brno

Česká republika
Phone: +420 541562374

Mobil: +420607935908

E-mail: tomaseko@yahoo.com

http://www.vfu.cz/acta-vet/actavet.htm 


\section{Materials and Methods}

The tumour incidence among laying hens was monitored in three slaughterhouses (identified in this paper as slaughterhouses K, M and U) in the Czech Republic. Laying hens from the production and parent flocks brought to the slaughterhouses at the end of the laying period were examined. All the layers were between 16 and 19 months old. The tumour incidence in slaughterhouses M and K was monitored from January to June, 2003. Monitoring in slaughterhouse U took place from January to December, 2003. We examined 297277 hens from 21 flocks, 175304 hens from 14 flocks, and 587213 hens from 56 flocks in slaughterhouses K, M and U, respectively. A total of 1059794 laying hens from 91 flocks were examined.

Tests for antibodies against the leukosis/sarcoma viruses were made in hens from one randomly selected breeding flock and one production flock. Blood samples were collected from hens at the end of the egg-laying period. Blood samples from the breeding flock hens were collected into test tubes during exsanguination in the slaughterhouse $\mathrm{M}$ after mechanical decapitation of the hens. Blood samples from the production flock hens were collected into test tubes after the hens had been decapitated manually. A total of 115 samples were taken from every flock. The samples were centrifuged and the acquired serum was frozen.

Indirect ELISA tests (FlockCheck ${ }^{\circledR}$ : ALV Ab, IDEXX, USA) were used for serological investigation, and the final colouration was measured with a Shell Spectra II spectrophotometer (Tecan, Austria) connected to a computer using KIMW software (Schoeller Pharma, Czech Republic) with Windows 95 for necessary computations. The formula for calculation of titres was $\log _{10}$ Titer $=1.09\left(\log _{10} \mathrm{~S} / \mathrm{P}\right)+3.36$, where $\mathrm{S} / \mathrm{P}$ is a ratio of the sample and positive control mean. Value of the negative control mean was subtracted from the sample and positive control mean values before division. Following the instructions of the ELISA test producer, titres of 884 and higher were considered positive.

Tumour samples for the histological examination were collected from visceral organs of hens slaughtered at the end of the laying period in slaughterhouses M and U. The samples were collected from June 2003 to March 2004. They were fixed with $10 \%$ neutral formol (i.e. $4 \%$ formaldehyde), processed by standard methods and histological sections were stained with haematoxylin-eosin.

\section{Results}

Results of screening tests for neoplastic lesions in all of the slaughterhouses are summarized in Table 1. Neoplastic growths were found in hens from 16 out of 21 flocks tested in slaughterhouse $\mathrm{M}(86.2 \%)$, in all 14 flocks tested in slaughterhouse $\mathrm{K}(100 \%)$ and in 52 out of 56 flocks tested in slaughterhouse U (92.9\%). The neoplastic growths of visceral organs were found in laying hens in 82 out of the total of 91 flocks investigated $(90.1 \%)$. No tumours were found in 9 flocks $(9.9 \%)$. The tumour incidence of up to $0.5 \%$ was found in 62 flocks $(68.1 \%)$, it ranged from $0.6 \%$ to $1.0 \%$ in 17 flocks $(18.7 \%)$, and exceeded one percent in 3 flocks only (3.3\%). The total number of tumours found in all three flocks reached 3226 , which represented $0.3 \%$ of all examined layers.

Table 1. Flocks of laying hens of domestic poultry ranged by occurence of neoplasms

\begin{tabular}{|l|c|c|c|c|}
\hline $\begin{array}{l}\text { Incidence of } \\
\text { neoplasms in flock }\end{array}$ & $\begin{array}{c}\text { Slaughterhouse M } \\
(\mathrm{n}=21)\end{array}$ & $\begin{array}{c}\text { Slaughterhouse K } \\
(\mathrm{n}=14)\end{array}$ & $\begin{array}{c}\text { Slaughterhouse } \mathrm{U} \\
(\mathrm{n}=56)\end{array}$ & $\begin{array}{c}\text { All flocks } \\
(\mathrm{n}=91)\end{array}$ \\
\hline 0 & 5 & 0 & 4 & 9 \\
$0.1-0.5 \%$ & 14 & 12 & 36 & 62 \\
$0.6-1.0 \%$ & 2 & 2 & 13 & 17 \\
$>1 \%$ & 0 & 0 & 3 & 3 \\
\hline
\end{tabular}

Five types of tumours were identified by histopathological examination in 14 samples from slaughterhouses $M$ and $U$. Five of the tumours were diagnosed as pancreatic adenocarcinoma with metastases in the intestine serosa, three as adenocarcinoma of the oviduct, two as leiomyoma of the mesosalpinx, one as ovarian adenocarcinoma, and one as intestinal lymphoma of the mucous membrane. Two samples originally presumed to be tumours were subsequently diagnosed as pseudotumours of growths with a central eosinophilic mass and peripheral granulomatous reaction and were considered to be encapsulated egg yolks.

The serological tests showed that titres of all 230 serum samples collected from laying hens from both the parents and production flocks remained below the minimum level of 884 , 
and were, therefore, all negative for the presence of antibodies against the leukosis/sarcoma viruses.

\section{Discussion}

From the epizootological and economical points of view, herpes viruses (Marek's disease) and retroviruses (from the avian leukosis/sarcoma viral group) represent the most important causes of neoplasia in domestic fowl. Besides, tumours of unknown aetiology are also frequently reported (Reece 2003).

Our tumour screening tests showed that neoplasias in egg-laying hens of the domestic fowl are relatively infrequent. In $86.8 \%$ of the flocks slaughtered, the tumour incidence remained below one percent and no neoplastic growth was found in $9.9 \%$ of the flocks. The neoplasia included, in the order of frequency, pancreatic adenocarcinoma with metastases in the intestines, adenocarcinoma of the oviduct, leiomyoma of the mesosalpinx, ovarian adenocarcinoma, and lymphoma of the intestine wall. Similar findings were reported in a SPF flock from the USA, where the following tumours were identified: adenocarcinoma of the ovary and oviduct, leiomyoma of the mesosalpinx, pancreatic adenocarcinoma, hepatocellular carcinoma, cholangiocellular carcinoma, parabronchial adenocarcinoma, adenocarcinoma of the proventriculum and mezothelioma (Fredrickson 1987). Another study in an Australian SPF flock of laying hens suggested that the spectrum of tumours might be even greater after having diagnosed the following tumour types: lymphomas, fibrosarcomas, metastatic abdominal adenocarcinoma, myelocytoma, reticular cell sarcoma, abdominal liposarcoma, subcutaneous lipoma, renal adenocarcinoma, ovarian tumour of granulous cells, and adrenocortical adenoma (Reece et al. 1996).

A low incidence of nodular tumours of the reproduction tract of laying hens $(0.3 \%)$ diagnosed as adenocarcinoma was also reported from slaughterhouses in Ireland (Talebi et al. 1993). By contrast, a study of reproduction disorders in laying hens in England revealed neoplasia in 34\% of laying hens (Lewis et al. 1992). In the USA, the prevalence of adenocarcinomas of the oviduct in laying hens ranged from $5 \%$ to $81 \%$ of the population (Goodchild et al. 1969). Positive correlations between the tumour incidence, body weight of adult laying hens, and egg weight were reported by several other authors (Anjum 1987). Adenocarcinoma of the oviduct appeared to be the most frequent diagnosis and should be distinguished from the ovarian adenocarcinoma, which is improbable in laying hens younger than 1 year as there is no evidence for the hypothesized hormonal unbalance aetiology in young hens (Fredricks on 1987). Other studies of tumours in SPF flocks suggested that tumours might occasionally be caused by factors of non-viral origin (Crittenden 1981), and are classified as tumours of unknown aetiology. The incidence of such tumours is low world-wide and further systematic monitoring is needed. One tumour type of unknown aetiology is leiomyoma of the mesosalpinx. Its prevalence in SPF and commercial flocks of laying hens is between 0 and $60 \%$ at the end of the egg-laying period. Higher concentrations of circulating 17- $\beta$ - estradiol (Anjum and Payne 1988) were demonstrated in affected laying hens. Results of the histological examination of our samples and the low tumour incidence suggest that aetiology of these tumours is most likely nonviral.

The low tumour prevalence was in accordance with the results of the serological tests for the presence of antibodies against the leukosis/sarcoma viruses from subgroups A and B. All samples from both the breeder and commercial flocks were evaluated as negative. The virus is, nevertheless, repeatedly found on poultry farms throughout the world. Tests carried out in four breeder flocks of laying hens in Poland in 1991 showed positive results in 6.1 to $30.1 \%$ (Minta et al. 1991). Similarly in Taiwan, 5.9\% of laying hens (and up to $15 \%$ of broilers) were tested positive (Lin et al. 2000). In Turkey, 3.1 - 28.9\% of laying hens (and 
from 10 to $42.1 \%$ of egg whites) were also found to be positive (S en et al. 2000). In Europe, the occurrence of the virus in 2002 was reported from Belarus, France, Germany, Ireland, Malta, the Netherlands, Rumania and Northern Ireland (UK). In Hungary and Slovakia, the virus was last detected in 2001 and 1997, respectively (OIE 2003).

The negative results of the serological examinations seem to indicate that the hens from the screened populations have probably never been in contact with the avian leukosis viruses, as the horizontal leukosis/sarcoma viral infections induce the production of virus-neutralizing antibodies which persist for life-time (F adly and Payne 2003). This was a surprising finding as the leukosis/sarcoma viruses in the domestic fowl populations are regarded as ubiquitous, even though the cases of clinically demonstrable neoplasias are rare (F adly and Payne 2003). The low incidence of antibodies has also been reported from Switzerland. Although positively tested birds were found in $28.1 \%$ of flocks, the overall number of positive samples was only $3 \%$ (Wunderwald et al. 2002). It is likely, according to these results, that the leukosis/sarcoma viruses belonging to subgroup $\mathrm{A}$ and $\mathrm{B}$ are decreasing in the populations of layers in Europe. In the light of our findings (the low tumour incidence and detection of no antibodies in one breeding and one production flock), the situation in the Czech Republic appears to be rather similar. However, in order to be able to confirm or exclude the occurrence of the leukosis/sarcoma viruses in the populations of layers in the Czech Republic, further monitoring is necessary.

\section{Prevalence nádorů a protilátek proti leukózo-sarkomovým virům podskupin A a B u nosnic}

Viry leukózo-sarkomového komplexu jsou častými původci nádorových onemocnění u drůbeže. Cílem této studie bylo zjistit četnost výskytu nádorů a prevalenci protilátek proti leukózo-sarkomovým virům podskupiny A a B u nosnic kura domácího (Gallus gallus f. domestica) rodičovských a užitkových chovů v České republice. Př́tomnost nádorů byla sledována na porážkách u celkem 91 chovů nosnic a bylo zjištěno, že prevalence nádorových změn je nízká. Nádory se vyskytly v 82 chovech $(90,1 \%)$, ale v 62 chovech $(68,1 \%)$ incidence nepřekročila půl procenta a pouze ve 3 chovech $(3,3 \%)$ byla vyšší než jedno procento. V 9 chovech $(9,9 \%)$ se nádory nevyskytovaly vůbec. Pro zjištění spektra vyskytujících se nádorů bylo histopatologicky vyšetřeno 14 náhodně odebraných vzorků. Nádory vyšetřené u nosnic na konci snášky byly histogeneticky pestré. Zahrnovaly pět adenokarcinomů pankreatu, tři adenokarcinomy vejcovodu, dva leiomyomy závěsu vejcovodu, po jednom adenokarcinom vaječníku a lymfom stř̌eva. Byly zaznamenány i dva př́ipady pseudotumorů, pravděpodobně opouzdřených žloutkových koulí. Sérologické vyšetření vzorků krve bylo provedeno metodou ELISA v užitkovém a rozmnožovacím chovu nosnic. $\mathrm{V}$ žádném $\mathrm{z}$ vyšetřených chovů nebyla zjištěna prítomnost protilátek proti leukózo-sarkomovým virům podskupiny $\mathrm{A} \mathrm{a} \mathrm{B}$.

\section{Acknowledgements}

This study was supported by the Research Plan MŠMT 161700002 of the Ministry of Education, Youth and Sports of Czech Republic and by the grant project GAČR 524/01/0866 of the Grant Agency of Czech Republic.

\section{References}

ANJUM AD 1987: Adenokarcinoma of the oviduct of the domestic fowl (Gallus domesticus) and its relationship to steroid hormones. PhD Thesis, Royal Veterinary College, London, $356 \mathrm{p}$.

ANJUM AD, PAYNE LN 1988: Spontaneous occurence and experimental induction of leiomyoma of the ventral ligament of the oviduct of the hen. Res Vet Sci 45: 341-348

CRITTENDEN LB 1981: Exogenous and endogenous leukosis virus genes - A review. Avian Pathol 10: $101-112$

FADLY AM, PAYNE LN 2003: Leukosis/Sarcoma Group. In: SAIF YM, BARNES HJ, GLISSON JR, FADLY AM, MCDOUGALD LR, SWAYNE DE (Ed.): Diseases of Poultry. Iowa State Press, Ames, pp. 465-516

FRANO J, SCAPKINOVA E, VANEKOVA M, SVEC R 1982: Detection of leukosis on brown Leghorn chicken farms. Vet Med (Praha) Aug 27: 503-508 
FREDRICKSON TN 1987: Ovarian tumors of the hen. Environ Health Perspect 73: 35-51

GOODCHILD WM 1969: Some observations on Marek's disease (fowl paralysis). Vet Rec 84: 87-89

LEWIS PD, LONG SE 1992: Incidence of non-laying in domestic hens. Br Poult Sci 33: 289-295

LIN ML, LIU HJ, YANG CS, KUO LC, HUANG WL 2000: Serological survey on the prevalence of avian leukosis in chickens in Taiwan by enzyme-linked immunosorbent assay. J Chin Soc Vet Sci 26: 161-166

MINTA Z, DAMBRINE G, COUDERT F, KARCZEWSKI W 1991: Application of DAS-ELISA test for detection of avian leukosis virus infection in basic breeding flocks in Poland. Bull Vet Inst Pulawy 34: 23-25

OIE Handistatus II Multiannual animal disease statut (online).c2003, last revision 28th of November $2003<$ http://www.oie.int/hs2/sit mald freq pl.asp?c co nt=4\&c mald=167>. Accessed December 7, 2003

REECE RL 1996: Some observations on naturally occurring neoplasms in domestic fowls in the state of Victoria. Avian Pathol 25: 407-447

REECE RL 2003: Other tumors of unknown etiology. In: SAIF YM, BARNES HJ, GLISSON JR, FADLY AM, MCDOUGALD LR, SWAYNE DE (Ed.): Diseases of Poultry. Iowa State Press, Ames, pp. 465-516

SEN A, ULGEN M, OZBILGIN S 2000: Detection of avian leukosis virus group specific antigen in egg albumen and sera samples by using ELISA. Bornova Vet Kont Arast Enst Derg 25: 39-45

TALEBI A, COLLINS JD, DODD K 1993: An investigation of nodular lesions found in Irish poultry during veterinary inspections at poultry meat plants. Avian Pathol 22: 715-724

WUNDERWALD C, HOOP RK 2002: Serological monitoring of 40 Swiss fancy breed poultry flocks. Avian Pathol 31: 157-162 

Tomášek O. et al.: Prevalence of Tumours ... pp. 575-579

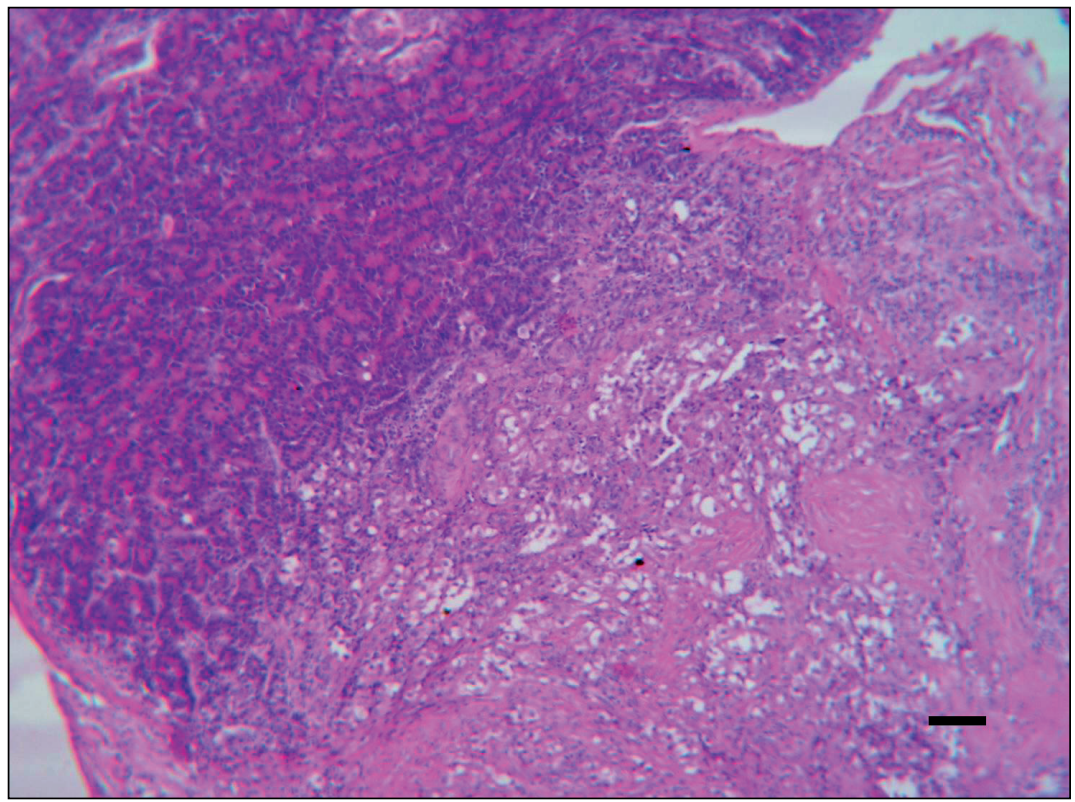

Fig. 1. Adenocarcinoma of the pancreas. Bar represents $150 \mu \mathrm{m}$.

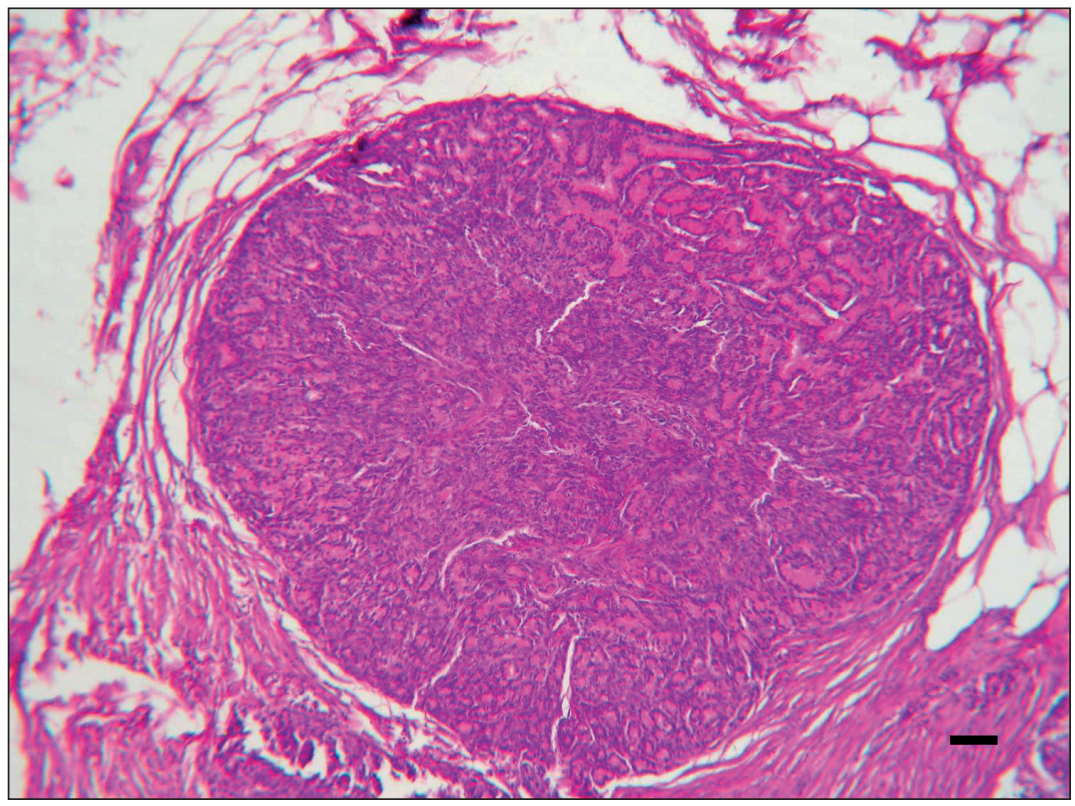

Fig. 2. Metastasis of adenocarcinoma of the pancreas in the serosa of the intestine. Bar represents $200 \mu \mathrm{m}$. 


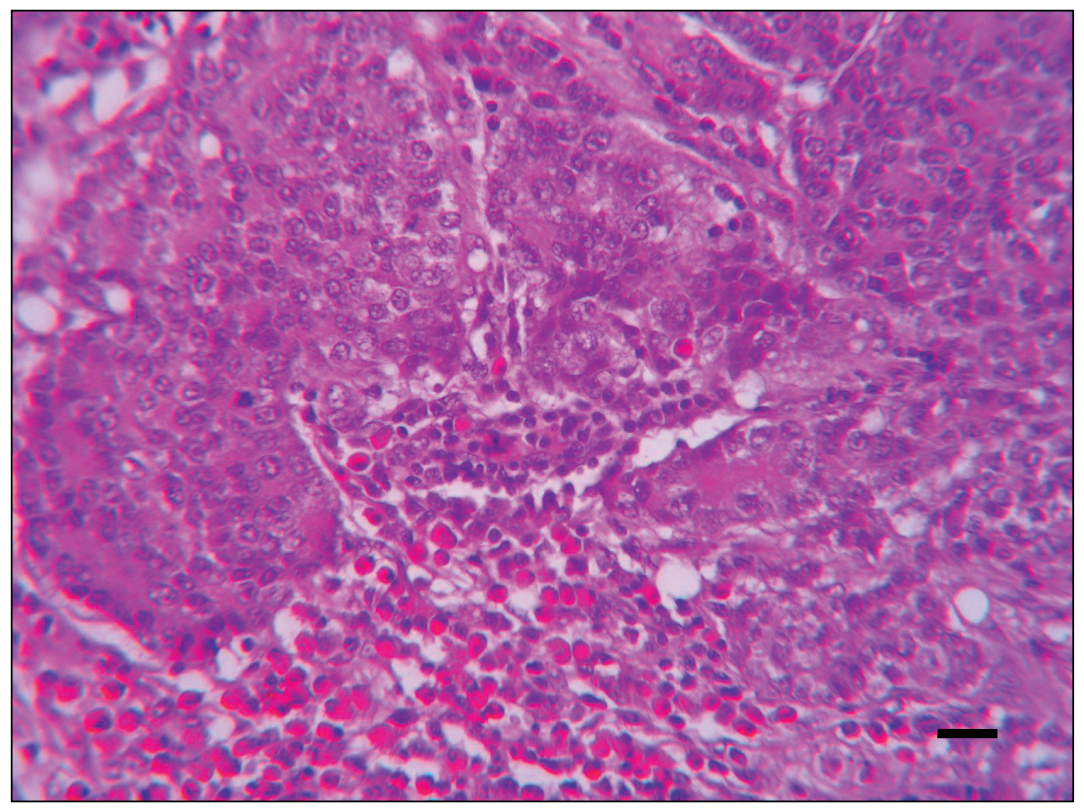

Fig. 3. Adenocarcinoma of the ovary. Bar represents $50 \mu \mathrm{m}$.

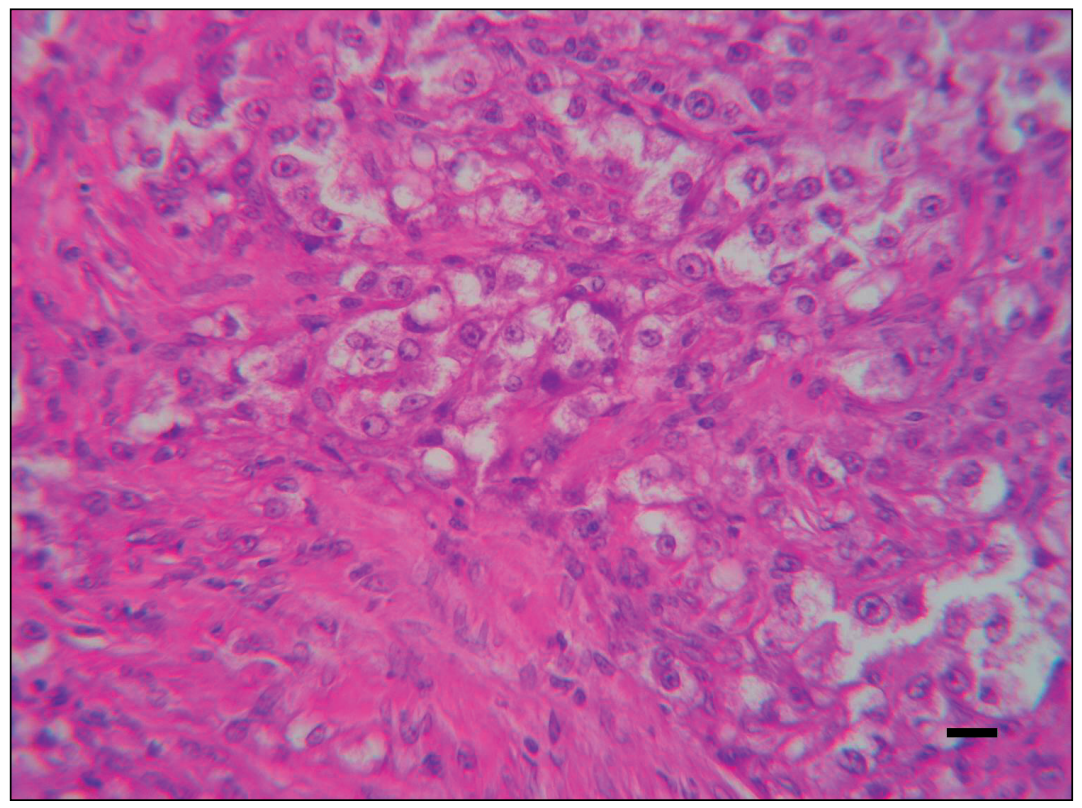

Fig. 4. Adenocarcinoma of the oviduct. Bar represents $30 \mu \mathrm{m}$. 


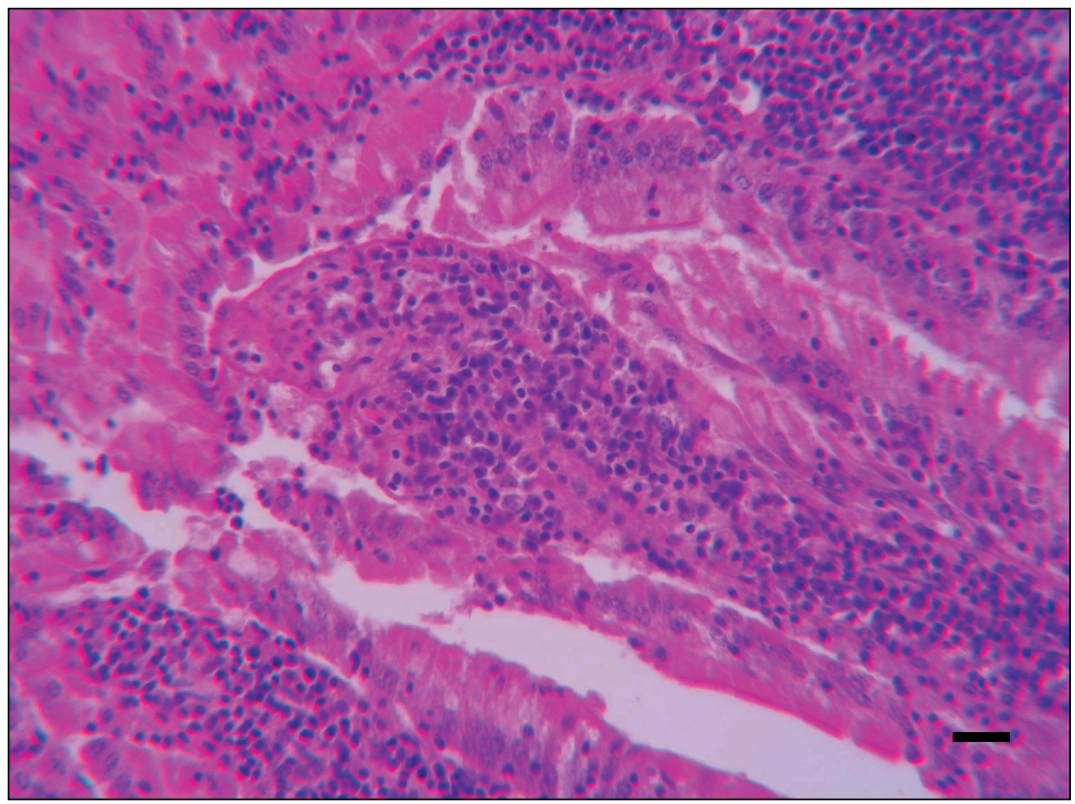

Fig. 5 Lymphoma of the mucous membrane of the intestine. Infiltration of the mucosa by uniform lymphocytes. Bar represents $50 \mu \mathrm{m}$.

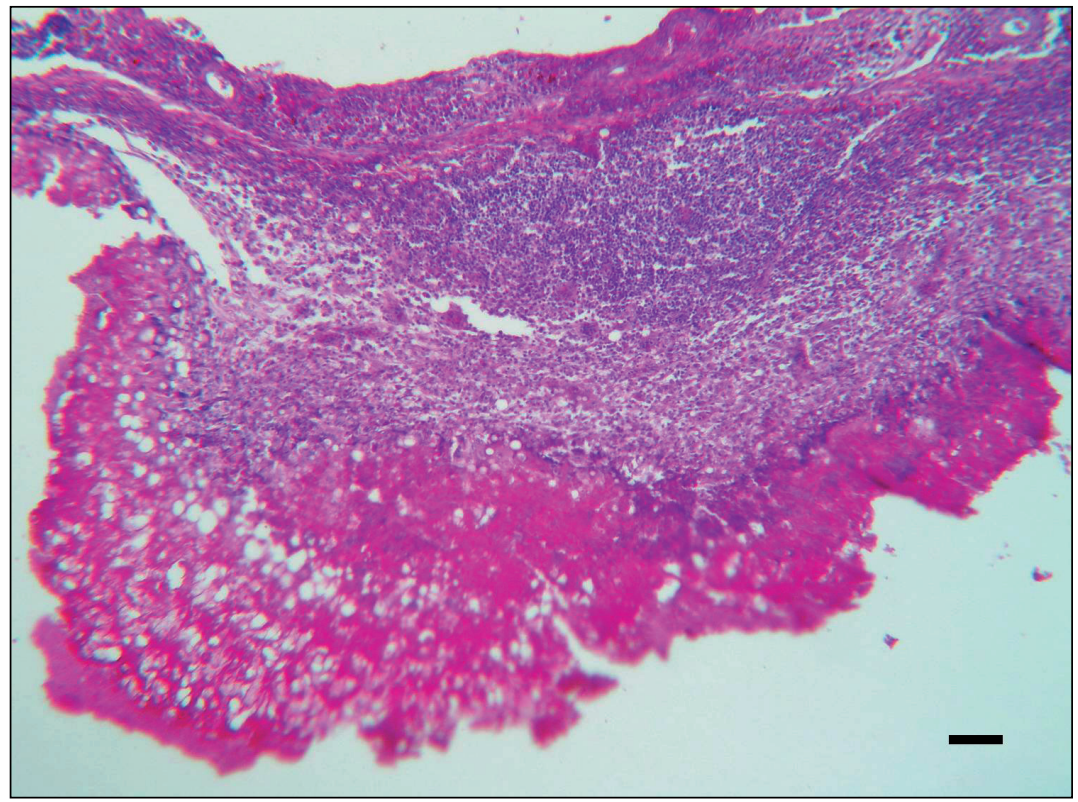

Fig. 6. Pseudotumor in the ovary. Eosinophilic mass (in the lower part) and peripheral granulomatous reaction. Bar represents $200 \mu \mathrm{m}$. 
